\title{
Whey powder in the preparation of special bread
}

\author{
${ }^{1}$ Delmi Bouras Amina, ${ }^{1}$ Megatli Smail, and ${ }^{2}$ Dilmi Bouras Abdelkader \\ ${ }^{1}$ Saad Dahleb Blida University, Algeria \\ ${ }^{2}$ Natural Bioresource Laboratory, H.B. Chlef University, Algeria
}

\begin{abstract}
Algeria imports more than half of her needs for milk and cereals. Faced with this situation, she must now think of finding a way to reduce this dependence by replacing cow's milk, in part, with another commodity abundant in the world and cheaper. In this work we used whey powder in bread making. The results showed that $71.5 \%$ of tasters found that PA bread $(100 \%$ whey) was extremely pleasant. The breads obtained have optimal characteristics with a beautiful appearance including a good appearance, regular shape and a smooth crust. The interior is also pleasant, with a very supple crease, little elastic, non-sticky and easy tearing. These good rheological characteristics are the result of a good balance between elasticity and extensibility. The whey breads have kept a good quality (organoleptic and microbiological) after 7 days of storage at $6^{\circ} \mathrm{C}$ in plastic packaging.
\end{abstract}

Key words: whey, specialty breads.

\section{Introduction}

Algeria imports more than $70 \%$ of these needs with an annual bill exceeding one billion dollars. In addition, we are the world's largest consumers of bread per person [1]. To sustain itself, Algeria imports more than $60 \%$ of these cereal needs. Bread is a very important part of the diet and does not provide enough protein. The price of its two strategic foodstuffs is increasing, given the significant and ever-increasing global demand [2]. Whey, a by-product of cheese making or casein production, can be defined as decaseinated milk. It has become essential to treat it to avoid environmental pollution [3]. The interest in whey powder depends essentially on the protein fraction, lactose and the water-soluble vitamins it contains [4]. This powder is less expensive than milk powder $[5,6]$. To this end, we are interested in the substitution of milk with whey, a product more available, protein quality and reduced prices in the manufacture of highly consumed food in Algeria and around the world. In this work, we used whey powder for various reasons :

- Get rid of the environment of this bulky waste and very polluting;

- Valorization of a rich and low-cost by-product. It is possible to produce whey-based foods at affordable prices and rich in protein, lactose, and water-soluble vitamins without relying on eggs, 
meat and dairy products that weigh heavily on the economy and the environment;

- Allow certain casein intolerants to safely consume whey breads, creams, ice creams ...

\section{Material and methods}

This work was carried out at the PPCA laboratory of the Hassiba Ben-Bouali Chlef University, as part of an agreement between the LBRN Laboratory and the Lactamel group of Sidi-Belabès.

\subsection{Material}

\subsubsection{Raw material}

The whey powder used comes from the European Union, imported by the Lactamel group of SidiBelabès. Bacteriological and chemical specifications are known. It is a stabilized powder between demineralized whey and vegetable fat, It is a dairy preparation that can be used for many applications (pastry cream, ice cream, baked goods...).

\subsubsection{Other ingredients}

We used other ingredients from the trade: milk, water, flour.

\subsection{Methods}

The food preparations we have chosen are milk bread and whey bread. Different dairy liquids have been prepared using whey powder :

$\neg 100 \%$ milk : $10 \mathrm{~g}$ of milk powder in $90 \mathrm{ml}$ of water : control sample $=\mathrm{L} 0$,

$\neg 50 \%$ of milk powder $(5 \mathrm{~g})+50 \%$ of whey powder $(5 \mathrm{~g})$ in $90 \mathrm{ml}$ of water $=\mathrm{L} 50$.

$\neg 100 \%$ whey : $10 \mathrm{~g}$ of whey powder in $90 \mathrm{ml}$ of water $=\mathrm{L} 100$.

To elucidate the effect of the concentration of whey powder on the quality of our products; we prepared three bread samples : $-\underline{\text { Bread A }}=\mathrm{PA}=\mathrm{L} 100+$ other ingredients, $-\underline{\text { Bread } \mathrm{B}}=\mathrm{PB}=\mathrm{L} 0+$ other ingredients, $-\underline{\text { Bread } \mathrm{C}}=\mathrm{PC}=\mathrm{L} 50+$ other ingredients.

\subsubsection{Preparation of bread}

For $100 \mathrm{ml}$ of dairy liquid (L0 or L50 or L100) we add: $5 \mathrm{~g}$ of yeast, $20 \mathrm{~g}$ of sugar, $30 \mathrm{~g}$ of egg, $12.5 \mathrm{ml}$ of oil and $200 \mathrm{~g}$ of flour. The whole is in a casserole and heated to $70-80^{\circ} \mathrm{C}$.

The method used for the preparation of bread consists of :

Pour the flour, sugar, salt, yeast and liquid slag. Knead pendant 4 to 5 minutes until a texture close to that of bread is obtained. Add the oil to the dough. Lay the dough on the flour worktop and shape 
into a ball then put it in a salad bowl. Cover with a cling film and let stand in the hottest part of the room. The dough must double in volume. Fold down the dough to degas it and then cut it into a portion of about $40 \mathrm{~g}$ that you put on. Place the rolls on a plate of four parsnips. Cover and let place an hour again in the hottest part of the room. They must double in size.

With a beaten egg, roll the buns and cut them on the top with a chisel. This will allow the steam to escape and small pains to better inflate. Heat the four to $180^{\circ} \mathrm{C}$ and cook for 15 to 20 minutes. The cooking is reached when the pains are well gilded and sound hollow.

\subsubsection{Evaluation of the organoleptic quality of breads}

The hedonic notation test is chosen for this sensory evaluation for the following reasons. It is not expensive, does not require specialized tasters and allows to compare the consumer's appreciation of different samples [7].

For the tasting (70 volunteers) we chose the three types of bread: PA, PB, PC. Volunteers are chosen at random, of different sexes and ages (20 to 60 years). Everyone is invited to taste a piece of each bread; then evaluate them by giving a score of 1 to 9 on the scoring sheet that was developed according to the 9-point hedonic scale.

\subsubsection{Evaluation of the physicochemical quality}

The physicochemical characterization of the different samples was made by the determination of their dry matter, the humidity and the monitoring of their $\mathrm{pH}$ during 7 days of storage at $6{ }^{\circ} \mathrm{C}$.

\subsubsection{Determination of $p H$}

Performed using $\mathrm{pH}$ meter. The $\mathrm{pH}$ reading is done on the screen after stabilization.

\subsubsection{Determination of the total dry extract}

Also according to ISO [8] which consists of : Weigh $5 \mathrm{~g}$ of bread, put in a kneaded glass box; dry and tare, then introduce the sample into the oven at $103^{\circ} \mathrm{C}$ for 3 hours, 1 hour and $1 / 2$ hour. The dry extract of the bread is expressed in mass percentage by the following formula:

(M1-M0) / (M2 - M0) x100

M0: Mass in grams of the empty cup.

M1: Mass in grams of the cup and the residue after desiccation.

M2: Mass in grams of the cup and the test sample.

\subsubsection{Determination of the moisture content}

Moisture is calculated by the following formula : H\% $=\mathbf{1 0 0}-$ TDE \% TDE: Total Dry Extract \% 


\subsubsection{Bacteriological analyzes}

The bread samples were subjected to a bacteriological analysis, or we carried out the research and, in case of presence, the enumeration of the germs prescribed in table 1 . These seeds are obligatorily sought in these products according to the Algerian norm.

Table 1. Growth conditions of the desired germs in characteristic medium

\begin{tabular}{ll}
\hline \multicolumn{1}{c}{ Germ sought } & $\begin{array}{c}\text { Growth condition } \\
\text { (aerobically) }\end{array}$ \\
\hline Mesophilic anaerobic total flora & $37^{\circ} \mathrm{C} / 24 \mathrm{~h}$ \\
Total coliforms & $37^{\circ} \mathrm{C} / 24 \mathrm{~h}$ \\
Fecal coliforms & $44^{\circ} \mathrm{C} / 24 \mathrm{~h}$ \\
Salmonella & $37^{\circ} \mathrm{C} / 24 \mathrm{~h}$ \\
Staphylococcus aureus & $37^{\circ} \mathrm{C} / 24 \mathrm{~h}$ \\
Yeasts and molds & $25^{\circ} \mathrm{C} / 5 \mathrm{j}$ \\
\hline
\end{tabular}

The search and enumeration of these germs is carried out according to the ISO [8] standard which consists in :

- Prepare decimal dilutions. Aseptically carry from the chosen dilution $1 \mathrm{ml}$ and pour it on the surface of the box in case of research and in depth in case of enumeration.

- Incubate the dishes according to the growth conditions indicated in Table 1.

\section{Results}

\subsection{Organoleptic characteristics of breads}

The organoleptic quality of the three bread samples ( $\mathrm{PA}_{\mathrm{A}} \mathrm{PB}_{\mathrm{B}}$ and $\mathrm{PC}$ ) was evaluated by 70 tasters and the results found are shown in Figure 1. The overall assessment of the results shows that:

$-71.5 \%$ of tasters find that PA bread (100\% whey) is extremely pleasant and gives it a score of 9. - 57\% of tasters find that $\mathrm{PB}$ bread (at 0\% whey) is neither pleasant nor unpleasant and gives it a score of 5 .

$-50 \%$ of tasters find that PC bread (50\% whey) is pleasant and gives it a score of 7. 


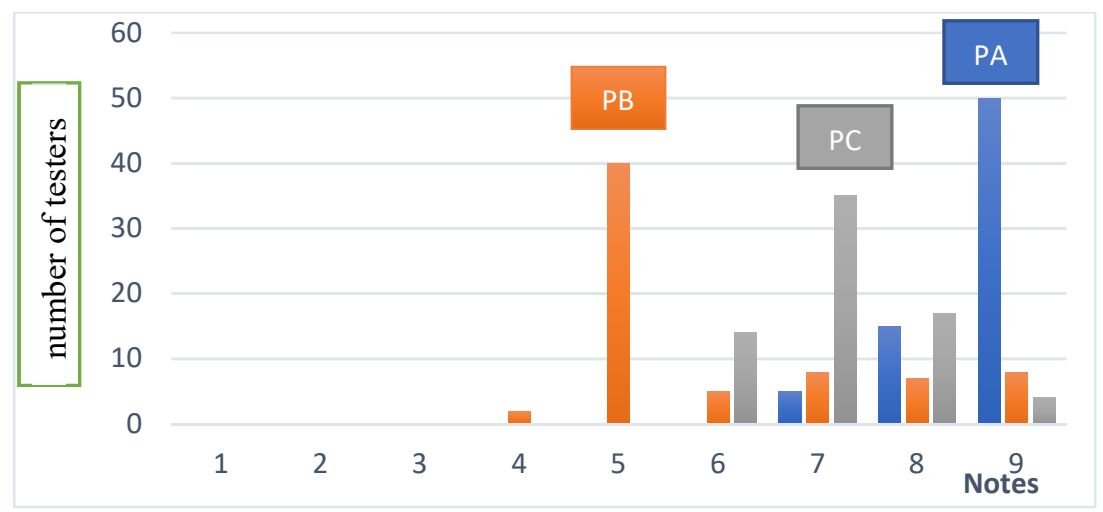

Figure 1: Graphical representation of the breads grading test results
1. extremely unpleasant 2 . very unpleasant
3. unpleasant
4. quite unpleasant
5. neither pleasant nor unpleasant
6. quite pleasan
7. Pleasant
8. Very nice
9. Extremely pleasant

The different organoleptic characteristics are different according to the composition of the bread and the results of the tests of appreciation of this quality are given in Table 2 .

Table 2: Organoleptic characteristics of different breads : Consumer reviews

\begin{tabular}{lccc}
\hline $\begin{array}{c}\text { Character } \\
\text { Bread }\end{array}$ & PA & PB & PC \\
\hline Crust & Very crispy & Less crispy & Crispy \\
Texture & Very dimpled and lightly & Dimpled and lightly & Dimpled and lightly \\
Color & Very beautiful & Beautiful & Beautiful \\
Taste & Very good & Good & Very good \\
Aroma & Very good & Good & Very good \\
\hline
\end{tabular}

\subsubsection{External aspects of the different breads}

The breads obtained have optimal characteristics with a beautiful external appearance (Figure 2), including a good appearance, regular shape and a smooth crust. The crust color of PA and Pc breads (especially PA bread) was highly appreciated visually. The bread crust PA, according to the tasters, has a more pronounced color than bread $\mathrm{PB}$.

\subsubsection{Internal aspects of the different bread}

The PA sample showed the best crumb with a lot of cells and a very white color compared to the other 02 breads (PB and PC) (Figure 2). 

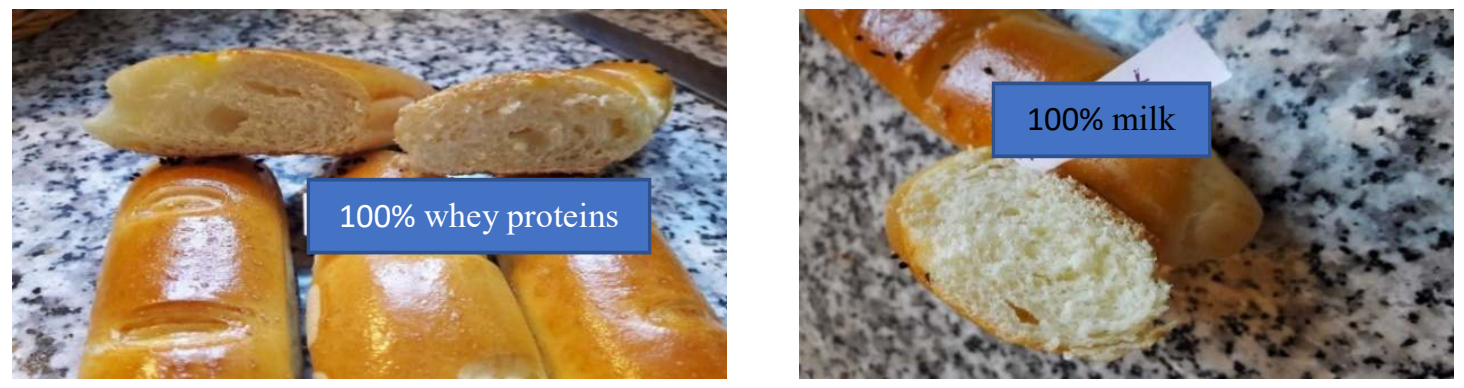

Figure 2: Appearance of bread crumbs with whey and milk (PA and PB)

\subsubsection{Flavor and taste of bread}

The best taste was attributed to the sample PA, then PC and finally PB; the tasters find that the bread of the sample PA has a good taste, better than that of the samples PC and PB respectively.

\subsection{Rheological characteristics of breads}

We followed the rheological characteristics of the various breads ( $\mathrm{PA}, \mathrm{PB}_{\mathrm{B}}$ and $\mathrm{PC}$ ) and the observations led us to conclude that:

- Crust : at first, the crust is smooth and crisp and after 1 hour it becomes soft and brittle. The crispness is not sought for milk breads.

- Mie : very soft, not elastic, not sticky and easy tearing.

During the preparation of the breads we noticed that the addition of whey led to :

- improvement of the dispersion of the fat during the aqueous phase,

- improved water retention and reduced losses during cooking,

- perfume improvement thanks to the presence of lactose,

- reduction of revenue costs,

- Increasing the elasticity of the dough.

\subsection{Preservation of breads}

We evaluated the characteristics of bread $\mathrm{PA}, \mathrm{PB}_{\mathrm{B}}$ and $\mathrm{PC}$ during storage (at room temperature and at $6^{\circ} \mathrm{C}$ ) in different packaging (paper, plastic) for a specific duration $(1,3,5$ and 7 days). The evolution of quality corresponds to a modification of texture and aroma properties over time [9].

The results show that packaged PA and PC breads preserved for up to 7 days in plastic or paper bags have a low water loss and thus a very slow hardening (Figure 3). Almost the same results are obtained with breads prepared with milk $\left(\mathrm{PB}_{\mathrm{B}}\right)$ and preserved under the same conditions, but with appearance of rancidity from the 5th day (Figure 4). 


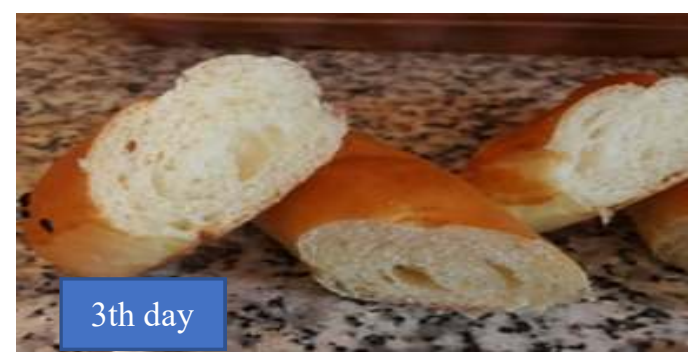

Figure 3: Appearance of PA bread

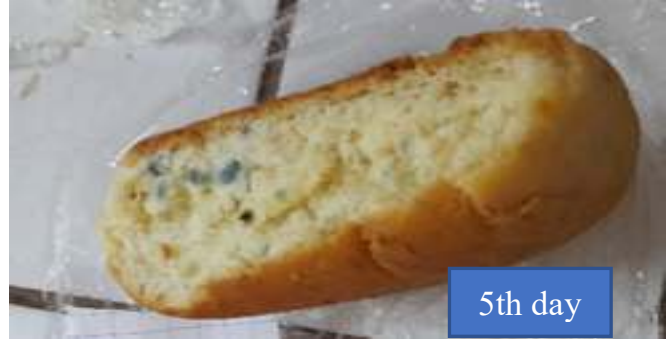

Figure 4: PB Bread with mold (rancid)

\subsection{Evaluation of the physico-chemical quality of breads}

\subsection{1. $\mathrm{pH}$}

Variations in $\mathrm{pH}$ values during storage of breads depend on the fermentation time and their initial $\mathrm{pH}$. For the 3 loaves the $\mathrm{pH}$ decrease is regular with time and remains very low (4 to 5\%).

\subsubsection{Total dry extract and moisture}

The determination of the water content is important since it determines the accuracy of the analytical results related to the dry matter or moisture content of the product. The results of the three bread samples are as follows : $\mathrm{PA}=26 \%, \mathrm{~PB}=30 \%$, and $\mathrm{PC}=28 \%$.

\subsubsection{Appreciation of the nutritional value of breads}

The nutritional value of the various breads $(\mathrm{PA}, \mathrm{PB}$ and $\mathrm{PC})$ is normally identical to that of ordinary breads. The only major difference is that the fat content is higher for whey breads (the powder contains $26 \%$ of the dry matter) than the milk bread (the powder contains $16 \%$ of the dry matter.

\subsection{Microbiological evolution of breads}

The results of bacterial counts (FAMT, total coliforms, faecal coliforms, Salmonellae, Staphylococcus aureus) of the various breads do not reveal any presence of colonies during the 7 days of storage. Similarly, the yeast and mold count and search results were negative for PA and PC breads, whereas for Рв bread (100\% milk) we noted the presence of a few colonies from the 5 th day of storage (Figure 4). Based on these results, we can conclude that $\mathrm{PA}$ and $\mathrm{PC}$ whey breads are free from bacteria for the entire shelf life (7 days). In addition, no contamination was recorded despite the absence of synthetic preservatives. 


\section{Discussions}

The AFNOR standard defines the organoleptic character as the property of a product perceptible by the sense organs (sight, smell, hearing, touch, taste). For the consumer, the notion of good bread or bad bread is closely related to these characteristics. From a professional point of view, the precise description, textures and tastes, allows a progress towards a better control of the know-how to answer to the precise expectations of the consumers [9].

The breads obtained have optimal characteristics with a beautiful external appearance. The crust should be smooth, shiny, free of blisters, colored, regularly browned, well adherent and crispy. The dark coloring of the loaves is influenced by the rise in the level of damaged starch, the total sugar levels and the available amino acids (proteins of whey) present in the flour [10, 11].

The loaves have airy cells, but in some cases they are poorly dispersed and non-homogeneous, this can be explained by the poor distribution or incorporation of $\alpha$-amylases. In spite of, this aspect the breads present, in general, an excellent internal aspect.

The creation of air inclusions keeps air pockets, in this case we cannot speak of "bubbles" or "holes" but caverns. The origin being a bad connection of the layers to the shaping and the bearing. The maintenance of air pockets in some places, will contribute with their expansion in the oven, the formation of large empty spaces. The crumb needs to be supple, elastic, with an airy texture, formed of honeycombs with fine and pearlescent walls, of a cream color in normal kneading or white in intensified kneading and the chews must be neither sticky nor hardy and offer beforehand everything from crunchiness.

The good rheological characteristics of the various breads are the result of a good balance between elasticity and extensibility, according to Ensmic [12]. Addition of whey reduces fermentation time [13]. At the time of cooking, the grains are more regular and the friability of the products is light because of changes in the glutinous network.

On the basis of these results, we found that the $\mathrm{P}_{\mathrm{A}}$ and $\mathrm{P}_{\mathrm{C}}$ batch had a good organoleptic quality compared to the $\mathrm{P}_{\mathrm{B}}$ batch, which means that there was a change in the organoleptic quality with the addition of the whey powder. Rancidity and loss of freshness is a bit slow during refrigeration.

Usually, bread sticks are kept in a bag of cotton, linen or paper to prevent drying out [1]. This protection allows the bread to breathe, delays the evaporation of the water it contains and has no impact on its taste. Thus, the bread will remain crisp, mellow and tasty longer.

The aromatic quality depends, in part, on the $\mathrm{pH}$ and lactic acid / acetic acid ratio (or QF fermentative quotient) [14]. During conservation, this minimal difference in $\mathrm{pH}$ was unmasked. 
This is probably due to the prolongation of the fermentation time and the low dose of salt used. QF depends on fermentation conditions and fermentation species. Homofermentary bacteria convert $85 \%$ of hexoses into lactic acid while heterofermentaries convert them to lactic acid, acetic acid / ethanol and $\mathrm{CO}_{2}$. Conducting fermentation by varying hydration, temperature, duration, ash content, and ingredients can influence QF.

Dry matter is much larger and moisture is less important when whey content is important. Because the latter is richer in fat that remains in the total dry extract.

The absence of microorganisms is logical results because the different breads were baked at a very high temperature. The presence of a few colonies from the 5th day of storage can be explained by the high water content in this sample : $30 \%$ versus $26 \%$ for PA bread or breads were put warm in the storage bags.

The different samples of whey bread can be safely consumed after 7 days of storage at $6^{\circ} \mathrm{C}$ in plastic packaging. The PA bread has kept almost the same organoleptic characteristics as those of the first day. The increase in the life of this bread can be explained by the addition of whey decreased the water content in both products so avoided microbial contamination, the preparation of our breads in accordance with good hygiene and manufacturing practices, and a package impermeable to moisture and air.

\section{Conclusions}

The overall assessment of the volunteer tasters shows that the three bread samples have good organoleptic characteristics with excellent external appearance : good appearance, regular shape and a smooth crust. The latter is brilliant, devoid of blisters, golden color, well adherent to the crumb and crispy. Similarly, the crumb is very flexible, elastic, airy texture, formed of cells with thin walls and pearlescent, with a chew neither sticky nor cardboard and offers a slight crispness. The flavor and taste of whey breads are better appreciated.

After 7 days of storage at $6{ }^{\circ} \mathrm{C}$ in plastic or paper packaging, PA bread has kept almost the same organoleptic characteristics as those of the first day. No contamination was recorded despite the absence of synthetic preservatives.

\section{Acknowledgements}

My heartfelt thanks go to Dr. Assal N., President of the Lactamel Group, for his help in acquiring whey powder. 


\section{References}

[1] Nemar F.. Potentiel nutritionnel et de panification d'une farine à pourcentage élevé en fécules de pomme de terre. Thèse de Doctorat, Université H.B. Chlef, Algeria ; 2015 ; 110p.

[2] Nemar F, Dilmi Bouras A, Koiche M, Assal N-E, Mezaini A and Prodhomme J. Bread quality substituted by Potato starch instead of wheat flour. Ital J Food Sci $2015 ; 27: 345-350$.

[3] Lachebi S. Valorisation des rejets de l'industrie laitière par technique membranaires (ultrafiltration). Mémoire de Magister ; Université M.B. Boumerdes, Algeria ; 2009, 151p.

[4] Ilker E, Mushsin C, Sebnem H. Separation of whey Components by using ceramic composite membranes. desalination $2006 ; 189: 87-91$

[5] Audic JC, Chaufer B, Daufin G. (). Non-food applications of milk components and dairycoproducts : A review. Lait $2003 ; 83: 417-438$.

[6] Schuck P, Bouhallab S, Durupt D, Vareille P, Humbert JP and al. Séchage des lactosérums et dérivés: rôle du lactose et de la dynamique de l'eau. Le Lait 2004 ; 84 (3) : 243-268.

[7] Boutrolle I. Mesure de l'appréciation des aliments par les consommateurs : état des pratiques et propositions méthodologiques [en ligne]. Thèse de doctorat, AgroParisTech 2007.

[8] ISO 6611. Lait et produits laitiers. Dénombrement des unités formant colonie de levures et/ou moisissures - Comptage des colonies à $25^{\circ} \mathrm{C} ; 2004$.

[9] Roussel P and Chiron H. (2002). Les pains français : évolution, qualité, production 2, France: MAE-ERT I Editeurs. ISBN/2-84601-693-3.

[10] Dupin H. Cuq JL, Malewiak MI, Leynaud-Rouaud C and Berthier AM. (). Alimentation et nutrition humaines. Ed. ESF éditeur, Paris. 1992 ; P56, 745-747.

[11] Boyacioglu MH and D'Appolonia BL. Characterization and Utilization of Durum Wheat for Breadmaking. I. Comparison of Chemical, Rheological, and Baking Properties Between Bread Wheat Flours and Durum Wheat Flours. Cereal Chem 1994 ; 71 : 21-28.

[12] Ensmic -Alimentation humaine. Les caractéristiques rhéologiques des pâtes, Condensé de cours - Annick Le Blanc 2007-2008.

[13] Vidra A, Németh A. Whey utilization in a two-stage fermentation process. Liquid Waste Recovery $2017 ; 2: 17-20$.

[14] Yuk HG, Marshall DL. Influence of acetic, citric, and lactic acids on Escherichia coli O157:H7 membrane lipid composition, verotoxin secretion, and acid resistance in simulated gastric fluid. J Food Prot. 2005 ; 68 (4) : 673-9. 